\title{
Impacts of Temperature and Rootstocks on Tomato Grafting Success Rates
}

\author{
Thibault Nordey \\ The World Vegetable Center, Eastern and Southern Africa, P.O. Box 10, \\ Duluti, Arusha, Tanzania; and CIRAD, UPR Hortsys, F-34398 Montpellier, \\ France
}

\section{Elias Shem}

The World Vegetable Center, Eastern and Southern Africa, P.O. Box 10, Duluti, Arusha, Tanzania

\section{Joel Huat}

CIRAD, UPR Hortsys, F-34398 Montpellier, France; and CIRAD, 97455 Saint-Pierre, La Réunion, France

\section{Additional index words. Africa, degree-days, heterografting, homografting, vegetable}

Abstract. Numerous studies have highlighted the merits of grafting to improve the performance of vegetable crops. However, the technique is hindered by several obstacles, including the synchronization of seedlings used as scions and rootstocks, and the effects of rootstocks and climatic conditions on grafting success rates. This study sought to gain insights into how such technical obstacles affect tomato grafting. An initial experiment conducted in a greenhouse set out to assess the relevance of using degree-days to predict the growth rates of seedlings used for grafting (i.e., stem diameters above cotyledons). The success rate for grafting a tomato variety (Tanya) on 10 different rootstocks from different species - namely tomato, eggplant, african eggplant, and a wild species-was assessed at different temperatures (i.e., $15,20,25,30,35$, and $40{ }^{\circ} \mathrm{C}$ ). The effects of grafting on plant vigor (i.e., fresh biomass), number of leaves, and plant height, and on the hydraulic conductivity of xylem vessels in the plant stem were assessed 2 weeks after grafting. The results show the advantage of using degree-days to predict the ready-to-graft stage of seedlings, as it reduced the discrepancy among trials. The grafting success rate was more than $90 \%$ at 15 and $20{ }^{\circ} \mathrm{C}$, but decreased significantly with higher temperatures, down to $20 \%$ at $40{ }^{\circ} \mathrm{C}$. Larger variations in growth rate for seedlings used as scions and rootstocks, a lower grafting success rate, and less vigor were recorded for heterografted plants than for homografted plants. The lower hydraulic conductivity measured in the stems of grafted plants, especially heterografted plants, was consistent with the lower plant vigor observed. Further studies are needed to investigate how grafting affects the hydraulic conductivity of xylem vessels in later developmental stages of grafted plants.

The environmental and human health impacts of chemicals used to control soilborne pathogens (e.g., methyl bromide, carbofuran, carbosulfan) have been raising concerns and have resulted in their gradually being phased out at various speeds depending on the countries involved. Efforts have been made to identify alternatives to pesticides, such

\footnotetext{
Received for publication 11 Sept. 2019. Accepted for publication 24 Oct. 2019.

Published online 7 January 2020.

This research was supported by GIZ within the GrAfrica project. We also appreciate long term strategic donors to the World Vegetable Center: Republic of China (Taiwan), UK aid from the UK government, Australian Centre for International Agricultural Research (ACIAR), Germany, Thailand, Philippines, Korea, and Japan.

T.N. is the corresponding author. E-mail: thibault. nordey@cirad.Fr.

This is an open access article distributed under the CC BY-NC-ND license (https://creativecommons. org/licenses/by-nc-nd/4.0/).
}

as using plant extracts (Deberdt et al., 2012), applying compost (Noble and Coventry, 2005) or compost tea (Mengesha et al., 2017), intercropping (Deberdt et al., 2015), and soil solarization (Krueger and McSorley, 2009). However, such methods do not wipe out soilborne pathogens, but only reduce their pressure for a time in the first soil layers. Improving plant resistance is believed to be the most suitable way of dealing with soil-borne diseases and has been considered in vegetable breeding programs for decades (Fufa et al., 2009; Melomey et al., 2019). Breeding efforts are hampered by the genetic diversity of soil-borne pathogens and the challenge of combining various agronomic traits, such as high yield, quality, and resistance to abiotic and biotic stress, in the same genotype. Grafting, the union of two plant parts - namely, a rootstock (base of the union to provide the root system) and a scion (the upper portion that carries the harvestable yield) - is seen as a complementary technique to breeding for combining the ge- netic potential of two plants. Although vegetable grafting has been known for a long time, it is being used increasingly worldwide on Solanaceae and cucurbit crops (Kubota et al., 2008; Lee et al., 2010). The merits of vegetable grafting for increasing resistance to abiotic and biotic stress have been discussed in several recent reviews, which stressed its potential for tackling food security issues (Keatinge et al., 2014; Rouphael et al., 2018). The broad genetic diversity of the Solanaceae family has encouraged researchers to improve the performance of tomato plants (S. lycopersicum) by using different rootstocks from the same species (homografting), but also from different species (heterografting), such as eggplant (S. melongena), african eggplant (S. macrocarpon and $S$. aethiopicum), and wild species (S. torvum and $S$. integrifolium) (Lee and Oda, 2003). Synchronizing the development of seedlings used as scions and rootstocks is one of the technical challenges of grafting, especially for heterografting. Seedlings of eggplant, african eggplant, and wild species used as tomato rootstocks are commonly sown from several days to several weeks before sowing scions, to ensure a similar stem diameter at the time of grafting. The synchronization of seedlings is particularly sensitive in nurseries, where climatic conditions are poorly controlled, as seedling growth rates vary with temperature. It would, therefore, be interesting to assess the accuracy of degree-days, a common indicator of plant phenology, to predict seedling development (Bonhomme, 2000; Brisson et al., 2003; Jones et al., 2003; Keating et al., 2003). The graft-take ratio, hereinafter called the grafting success rate, has been reported to vary with seasons (Huat, 2003). Guidelines on the optimum temperature range for tomato grafting vary considerably, depending on the authors, from 16 to $21^{\circ} \mathrm{C}$ (Kleinhenz et al., 2018) to 21 to $27^{\circ} \mathrm{C}$ (Rosskopf and Pisani, 2017) to 25 to $32^{\circ} \mathrm{C}$ (Black et al., 2003). An extensive study revealed that a constant temperature of $23{ }^{\circ} \mathrm{C}$ would appear to be the optimum for tomato grafting, and indicated that a temperature increase from 23 to $26{ }^{\circ} \mathrm{C}$ decreased the grafting success rate by $13 \%$ to $26 \%$, depending on the rootstock $(\mathrm{Vu}$ et al., 2013). Differences in grafting success rates among rootstocks were explained previously by discontinuities in the vascular bundles at the graft union (Kawaguchi et al., 2008).

After studying the advantages of using degree-days as an indicator of seedling growth rates, the impacts of temperature and rootstocks on grafting success rates were assessed using differences in plant vigor (i.e., fresh biomass), plant height, and the number of leaves. The hydraulic conductivity of xylem vessels in the stem was also measured to explain variations in plant vigor.

\section{Materials and Methods}

\section{Plant materials}

Seedlings of tomato, eggplant, african eggplant (S. aethiopicum), and a common wild species (S. elaeagnifolium) in Tanzania (Table 1) were obtained using seedling trays with a mix of sterilized soil (i.e., 1/3 soil, 1/3 
Table 1. Description of plant materials.

\begin{tabular}{|c|c|c|c|c|}
\hline Variety & Species & Origin & Description & Status \\
\hline Tanya & Solanum lycopersicum & WORLDVEG & $\begin{array}{l}\text { Open-pollinated variety, determinate } \\
\text { type with oblong fruit }\end{array}$ & Scion/rootstock \\
\hline Tengeru 1997 & Solanum lycopersicum & WORLDVEG & $\begin{array}{l}\text { Open-pollinated variety, semi-indeterminate } \\
\text { type with oblong fruit }\end{array}$ & Rootstock \\
\hline Tengeru 2010 & Solanum lycopersicum & WORLDVEG & $\begin{array}{l}\text { Open-pollinated variety, semi-indeterminate } \\
\text { type with round fruits }\end{array}$ & Rootstock \\
\hline Hawaii & Solanum lycopersicum & INRA & Open-pollinated & Rootstock \\
\hline Shelter & Solanum lycopersicum & Rizk Zwaan & Hybrid & Rootstock \\
\hline EG 203 & Solanum melongena & WORLDVEG & Open-pollinated & Rootstock \\
\hline EG 190 & Solanum melongena & WORLDVEG & Open-pollinated & Rootstock \\
\hline DB3 & Solanum aethiopicum & WORLDVEG & Open-pollinated & Rootstock \\
\hline Tengeru White & Solanum aethiopicum & WORLDVEG & Open-pollinated & Rootstock \\
\hline Wild & Solanum elaeagnifolium & Wild & Open-pollinated & Rootstock \\
\hline
\end{tabular}

compost, 1/3 sand). The seedlings were irrigated daily with a watering can and fertilizer was applied each week with a 17-17-17 NPK fertilizer solution diluted to $2.5 \mathrm{~g} \cdot \mathrm{L}^{-1}$. Grafted plants were obtained using the splice technique described by Black et al. (2003). Briefly, 3week-old tomato seedlings used as scions were grafted onto the varieties described in Table 1. The stems of the scions and rootstocks were cut obliquely at a $30^{\circ}$ angle above the cotyledons using sterilized blades. The surfaces of the cut scions and rootstocks were then gently joined together using a transparent plastic clip measuring $1.6 \mathrm{~mm}$ in diameter. The grafted plants were stacked and kept for $3 \mathrm{~d}$ in a healing chamber in the dark, then left to recover under artificial light $\left(5 \mu \mathrm{mol} \cdot \mathrm{m}^{-2} \cdot \mathrm{d}^{-1}\right)$ for $15 \mathrm{~d}$. Air moisture was maintained at $95 \%$ to $100 \%$ during the healing and recovery stages, whereas temperatures varied depending on the treatments described later.

\section{Experimental design and data collection}

Experiments were conducted from June to Dec. 2018 in the laboratory and greenhouses of the World Vegetable Center (WORLDVEG) in Tanzania (lat. -3.373 , long. 36.80, decimal degrees). The first set of experiments sought to compare the accuracy of calendar days and degree-days in predicting seedling growth rates for the varieties used in this study (Table 1). The second set of experiments sought to assess the impacts of temperature and rootstocks on grafting success rates, plant vigor, and the hydraulic conductivity of stem xylem.

Assessment of seedling development rates. Twenty seedlings per variety described in Table 1 were sown on four dates - namely, 8 June, 18 June, 20 July, and 10 Aug. Seedlings were laid out randomly in a greenhouse covered with insect-proof nets and polyethylene film on the roof. The stem diameter and plant height above the cotyledons of 10 of seedlings selected randomly per variety were assessed daily using a Vernier caliper. Such measurements were taken until the seedlings reach a suitable stem diameter for grafting (i.e., $1.6 \mathrm{~mm}$ based on our experience, hereinafter called the ready-tograft stage). The temperature and air moisture in the nursery were recorded every minute and averaged every $30 \mathrm{~min}$ using a data logger (HOBO Pro v2 U23-001; Onset Computer Corporation, Bourne, MA) placed under a perforated white shelter positioned $1.5 \mathrm{~m}$

Table 2. Climatic conditions recorded over the four trials to assess seedling growth rates.

\begin{tabular}{llcccc}
\hline Trials & Sowing date & $\begin{array}{c}\text { Mean temp } \\
\left({ }^{\circ} \mathrm{C}\right)\end{array}$ & $\begin{array}{c}\text { Maximum temp } \\
\left({ }^{\circ} \mathrm{C}\right)\end{array}$ & $\begin{array}{c}\text { Minimum temp } \\
\left({ }^{\circ} \mathrm{C}\right)\end{array}$ & $\begin{array}{c}\text { Air moisture } \\
(\%)\end{array}$ \\
\hline 1 & 8 June 2018 & 22.8 & 42.5 & 11.8 & 65.8 \\
2 & 18 June 2018 & 23.0 & 42.5 & 11.8 & 64.8 \\
3 & 20 July 2018 & 24.4 & 42.5 & 13.3 & 61.9 \\
4 & 10 Aug. 2018 & 24.2 & 42.5 & 13.3 & 63.4 \\
\hline
\end{tabular}

above the ground, with an open bottom section, to avoid direct exposure to solar radiation. The temperature and air moisture recorded during the four trials are summarized in Table 2.

Assessing the impacts of temperature and rootstocks on grafting success rates, plant vigor, and hydraulic conductivity. Variations in grafting success rates depending on the temperature were assessed by placing 10 nongrafted plants (i.e., control plants) and 10 plants grafted onto each variety described in Table 1 in separate climate chambers at $15,20,25,30$, 35 , and $40{ }^{\circ} \mathrm{C}$. Grafted and nongrafted plants were first placed in the dark for $3 \mathrm{~d}$, then left to recover under artificial light $\left(5 \mu \mathrm{mol} \cdot \mathrm{m}^{-2} \cdot \mathrm{d}^{-1}\right)$ for $15 \mathrm{~d}$. Air moisture was maintained above $95 \%$ during the healing and recovery stages using humidifiers. Data loggers (HOBO Pro v2 U23-001, Onset Computer Corporation) were placed in each climate chamber to record the temperature and air moisture every $30 \mathrm{~min}$. The climate data collected in the growing chambers are summarized in Table 3 . The grafting success rate for each treatment was assessed 2 weeks after grafting. At that time, five nongrafted plants and grafted plants of each rootstock from the $20{ }^{\circ} \mathrm{C}$ treatment (which displayed the greatest grafting success rate) were selected randomly. After measuring the fresh biomass above the grafting point (or above the cotyledons for nongrafted plants), the number of leaves, the plant height, and xylem conductivity in the stem at the grafting point were assessed on each plant using a methodology proposed by Melcher et al. (2012). Briefly, the stem section from $2.5 \mathrm{~cm}$ below to $2.5 \mathrm{~cm}$ above the grafting point was cut under water to avoid embolism. One end of the sample was wrapped in Teflon to avoid leakage, then connected under water to a water column $35 \mathrm{~cm}$ in height using a transparent flexible hose. Precautions were taken to avoid leakage and bubbles throughout the device. A beaker was placed under the free end of the sample to collect water. Thereafter, water was allowed to flow inside the samples for $24 \mathrm{~h}$. A constant pressure was maintained throughout the experiment by using a wide
Table 3. Climatic data recorded in climate chambers.

\begin{tabular}{lcc}
\hline $\begin{array}{l}\text { Climate } \\
\text { chambers }\end{array}$ & $\begin{array}{c}\text { Mean temp } \\
\left({ }^{\circ} \mathrm{C}\right)\end{array}$ & $\begin{array}{c}\text { Mean air moisture } \\
(\%)\end{array}$ \\
\hline 1 & $15.4 \pm 1.0$ & $97.4 \pm 8.5$ \\
2 & $20.1 \pm 0.8$ & $97.8 \pm 6.02$ \\
3 & $25.3 \pm 1.3$ & $99.1 \pm 3.7$ \\
4 & $30.0 \pm 1.2$ & $97.0 \pm 5.6$ \\
5 & $35.0 \pm 1.0$ & $96.8 \pm 6.1$ \\
6 & $39.5 \pm 1.0$ & $94.9 \pm 9.1$ \\
\hline
\end{tabular}

The data represent the mean \pm SD.

water reservoir (a syringe $5 \mathrm{~cm}$ in diameter). The amount of water flowing through the samples was assessed using a weighing scale to measure the quantity of water (measured in grams) collected in individual beakers. Xylem-specific conductivity $\left(\mathrm{K}_{\mathrm{s}}\right.$, measured in kilograms per megapascal per meter per second) was determined using Eq. 1, where $Q$ is the recorded flux (measured in grams per second), $L$ is the length of the segment (measured in meters), $\Delta P$ is the pressure drop across the segment (measured in megapascals), and $A_{s w}$ is the cross-sectional area of the conducting sapwood (measured in square meters), deduced from the stem diameter measured at the grafting point.

$$
\mathrm{K}_{\mathrm{s}}=\frac{Q \times L}{\Delta P \times A_{s w}}
$$

\section{Data analysis}

Because scant information was available in the literature for the basal temperatures to be used in calculating degree-days for the development of Solanaceous seedlings, these values were estimated using an iterative algorithm. For each species, linear regressions were established between the increase in stem diameters above cotyledons recorded during the four trials and the degree-days calculated with different basal temperatures (i.e., from 0 to $25^{\circ} \mathrm{C}$ with a $0.1^{\circ} \mathrm{C}$ step interval). The basal temperatures used in linear regressions exhibiting the lowest root mean square error 
Table 4. Differences in seedling growth rates for tomato rootstocks (i.e., the number of days or degree-days needed to reach the ready-to-graft stage and plant height at the ready-to-graft stage).

\begin{tabular}{|c|c|c|c|c|}
\hline Species & Variety & $\begin{array}{l}\text { Ready-to-graft stage } \\
\text { (calendar days) }\end{array}$ & $\begin{array}{l}\text { Ready-to-graft stage } \\
\text { (degree-days) }\end{array}$ & $\begin{array}{l}\text { Plant ht above cotyledons } \\
(\mathrm{cm})\end{array}$ \\
\hline \multirow{2}{*}{ Tomato } & Hawaii & $21.2 \pm 23(22.7 \%) * * * \mathrm{c}$ & $103.3 \pm 20.1(19.7 \%) * * d$ & $3 \pm 37.2 \mathrm{NS} \mathrm{ab}$ \\
\hline & Shelter & $21.6 \pm 18.2(18.3 \%) * * * \mathrm{c}$ & $105.3 \pm 15.4(15.7 \%)$ NS d & $3.2 \pm 34.6 \mathrm{NS} \mathrm{a}$ \\
\hline \multirow[t]{2}{*}{ Eggplant } & EG 203 & $35.5 \pm 25.5(25.1 \%)^{* * *} \mathrm{~b}$ & $189.2 \pm 21.6(21.1 \%)$ NS c & $2.5 \pm 35 \mathrm{NS} \mathrm{bc}$ \\
\hline & EG 190 & $35.2 \pm 19.2(19 \%)^{* * *} \mathrm{~b}$ & $187 \pm 14.6(14.4 \%)$ Ns c & $2.4 \pm 38.3 \mathrm{NS} \mathrm{bc}$ \\
\hline African eggplant & Tengeru White & $40.7 \pm 17.6(17.4 \%)^{* * *} \mathrm{a}$ & $309 \pm 17.4(17.2 \%) \mathrm{NS}$ ab & $2.1 \pm 32.5 \mathrm{NS} \mathrm{c}$ \\
\hline
\end{tabular}

The data represent the mean \pm the variation coefficient for the four trials. The relative root mean square error is within parentheses. Different letters indicate a significant difference in the column between varieties according to Tukey's test $(P=0.05)$.

NS, $* * *, * *$ Nonsignificant or significant at $P \leq 0.05,0.01$, or 0.001 , respectively, among trials for the same variety.

(RMSE) were selected. The relative RMSE (i.e., the ratio between the RMSE of predictions and the mean of all measurements) was used to compare the accuracy of the predictions of the ready-to-graft stage using calendar days or degree-days as indicators.

Analyses of variance were used on data exhibiting a normal distribution (i.e., the number of days or degree-days taken to reach the ready-to-graft stage and the height of the grafting points, along with the number of leaves, height, fresh biomass, and hydraulic conductivity of plants 2 weeks after grafting) to assess significant differences between treatments. Post hoc analyses were carried out when there were significant differences, with multiple comparison analyses of means using Tukey's honestly significant difference test. Kruskal Wallis tests were used on the data on the grafting success rate at different temperatures because they did not follow the normal distribution. All statistical analyses were carried out with $\mathrm{R}$ software ( $\mathrm{R}$ Development Core Team, 2012) using the agricolae package (De Mendiburu, 2014).

\section{Results}

Variations in seedling growth rates. The time taken to obtain ready-to-graft seedlings varied significantly among species, cultivars, and trials from 21.2 to $43.7 \mathrm{~d}$ (Table 4). The position of the grafting point (i.e., above cotyledons) of the tomato rootstocks was significantly greater than that of the other species. The basal temperature used to calculate degree-day exhibiting the lowest RMSE in linear regressions were 15.6, 15.2, 14.2, and $13.2{ }^{\circ} \mathrm{C}$ for tomato, eggplant, african eggplant, and the wild species, respectively. In contrast to the number of calendar days, the number of degree-days needed to obtain ready-to-graft seedlings did not vary among trials, except for the Hawaii and Tanya varieties. Lower relative RMSEs were obtained for the predictions of the ready-to-graft stage using degree-days as an indicator for most of the varieties.

Impact of temperature on the grafting success rate. Grafting success rates greater than $90 \%$ were obtained at 15 and $20^{\circ} \mathrm{C}$, but they decreased linearly with higher temperatures, down to less than $20 \%$ at $40{ }^{\circ} \mathrm{C}$ (Fig. 1). Some nongrafted plants died when the temper-

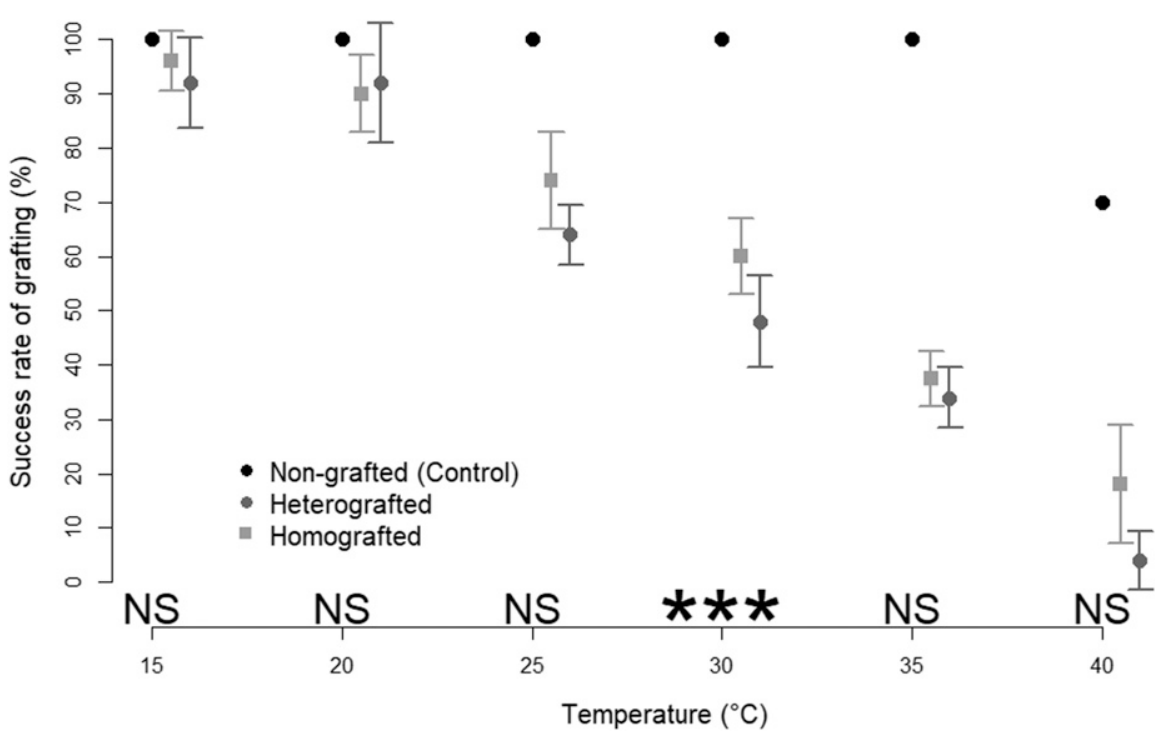

Fig. 1. Impacts of temperature on grafting success rates. The annotations Ns, *,**, and *** at the bottom of the graph indicated whether nonsignificant or significant differences in $P$ values of $0.05,0.01$, and 0.001 , respectively, were established between heterografted and homografted plants. The legends are indicated in the graph.

ature reached $40{ }^{\circ} \mathrm{C}$. Statistical analyses indicated that the success rate for heterografting was significantly less than for homografting at $30{ }^{\circ} \mathrm{C}$, but no significant differences were established at the others temperatures (Fig. 1).

Impact of rootstocks on grafted plant vigor. The fresh biomass of grafted plants above the grafting point was significantly less 2 weeks after grafting than that of nongrafted plants above the cotyledons, except for some tomato rootstocks (Tanya, Tengeru 2010, Tengeru 97) (Fig. 2A). Grafted plants were smaller (Fig. 2B) and had fewer leaves (Fig. 2C) than nongrafted plants. The hydraulic conductivity of xylem vessels in the stem of plants grafted onto eggplant, african eggplant, and the wild species was significantly less than that of the nongrafted plants. No significant difference was established between the hydraulic conductivity of nongrafted plants and that of plants grafted onto tomato rootstocks, except for plants grafted onto 'Hawaii'.

\section{Discussion}

Our results highlight the challenge of synchronizing the development of scion and rootstock seedlings when the temperature is not controlled, especially in the case of heterografting. Using degree-days to predict the ready-to-graft stage of seedlings reduced the variability among experiments. It is worth noting that the accuracy of predictions using degree-days is challenged by temperature forecasts under uncontrolled conditions. Nevertheless, this indicator can help to finetune the sowing schedule of rootstock and scion according to climatic conditions. The large relative RMSE values for the prediction of the ready-to-graft-stage using degree-day as an indicator suggest that factors other than temperature, such as light or air moisture, might be involved in the variations observed among experiments.

In line with a previous study ( $\mathrm{Vu}$ et al., 2013), our results show that grafting success rates decreased at high temperatures. These results highlight the need to keep grafted plants at low temperatures (i.e., 15 to $20{ }^{\circ} \mathrm{C}$ ) during the healing and recovery periods. Such temperatures are hard to maintain in low-cost healing chambers in warm climates, where outside temperatures can 

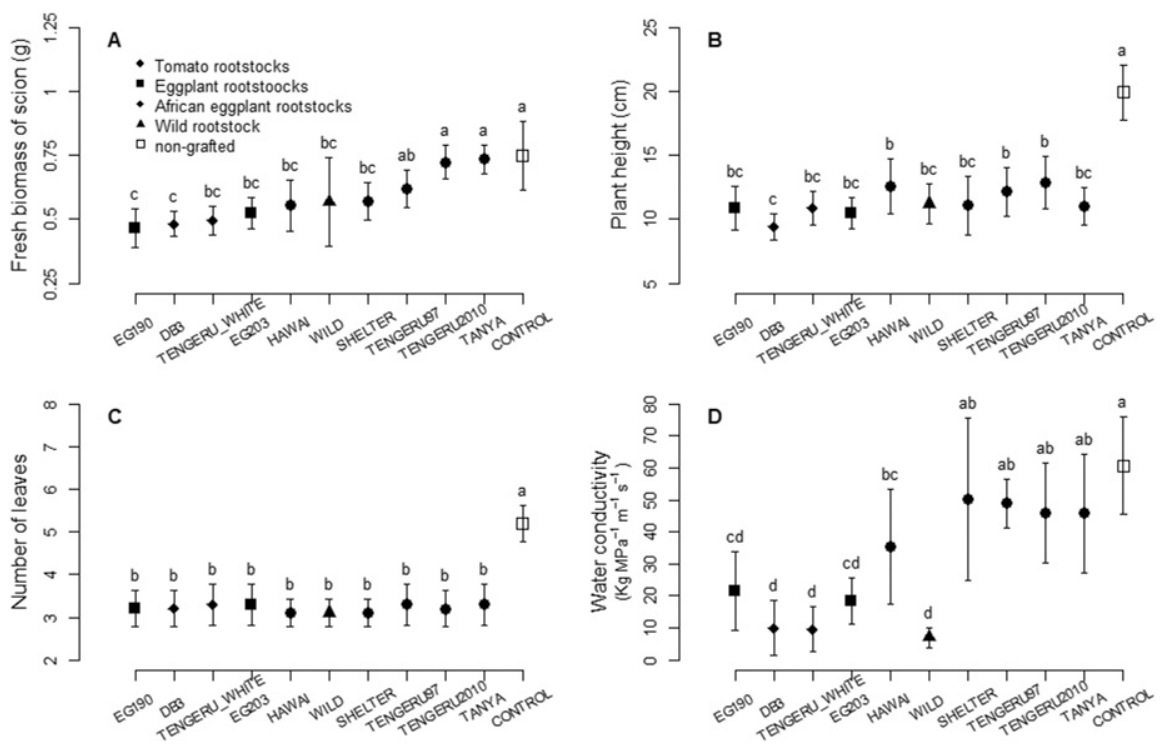

Fig. 2. Impacts of grafting and of the rootstocks used on the fresh biomass of the upper part of the plant (i.e., above the grafting point or above the cotyledons) for $(\mathbf{A})$ nongrafted plants, $(\mathbf{B})$ on plant height, $(\mathbf{C})$ the number of leaves, and (D) on the hydraulic conductivity of xylem vessels in the stem 2 weeks after grafting. Different letters mean the data differed significantly at $P<0.05$ (according to Tukey's multiple comparison test) among the rootstocks used.

exceed $30^{\circ} \mathrm{C}$. Under such conditions, using a zero-energy cooling chamber in dry and hot climates, or an underground healing chamber, would be helpful in reducing temperatures (Kitinoja, 2013).

The greater grafting success rate and the greater vigor measured for homografted plants than for heterografted plants confirmed the practical merits of using rootstocks of the same species (King et al., 2010). Nevertheless, greater resistance to abiotic and biotic stress, as well as the lower cost of seeds, may justify heterografting.

Our measurements brought to light the negative impact of grafting on the hydraulic conductivity of xylem vessels in the stem a few weeks after grafting. Similar results were reported previously on tomato by Kawaguchi et al. (2008), who used another method to assess hydraulic conductivity based on the migration of a dye within samples subjected to a vacuum. They explained the lower conductivity measured in grafted plants by discontinuities in the vascular bundles at the grafting points. The lower conductivity in grafted plants in comparison with nongrafted plants was consistent with the lower vigor (i.e., fresh biomass, plant height, and number of leaves). Our findings agreed with the previous study, presuming that grafting incompatibility could be explained in part by a reduction in assimilate translocation between the roots and the aboveground organs of the plant caused by a decrease in hydraulic conductivity (Kawaguchi et al., 2008).

It is worth noting that hydraulic measurements were taken in this study a few weeks after grafting, as done by Kawaguchi et al. (2008). Contrasting results might be obtained if measurements were taken at later developmental stages of grafted plants. This hypothesis is backed up by a previous study on olive

trees reporting that, although the grafted union represented the largest fraction of whole-plant hydraulic resistance within a few months after grafting, that proportion declined exponentially with time and became negligible after 1 year [i.e., less than $10 \%$ (Gascó et al., 2007)]. These findings are also supported by other studies on kiwifruit (Clearwater et al., 2004) and peach (Solari et al., 2006), reporting that the grafting point made just a small contribution to whole-tree hydraulic resistance at advanced stages of development. Further studies therefore need to assess changes in the contribution made by the grafting union to the total hydraulic resistance of grafted tomato plants up to the latest developmental stages. Such results would be of particular interest for tomato, because the growing period varies considerably from 4 months to more than a year, depending on the varieties used.

\section{Conclusion}

Although grafting can be useful for increasing the resistance of vegetables to abiotic and biotic stress, its implementation is hindered by technical obstacles. Large variations in the growth rates of seedlings complicate their synchronization for grafting, especially for heterografting and when climatic conditions are poorly controlled. Our results provide evidence of the merits of degree-days as an indicator for predicting the ready-to-graft stage of seedlings. Temperatures between $15{ }^{\circ} \mathrm{C}$ and $20{ }^{\circ} \mathrm{C}$ were maintained during the healing and recovery stages to obtain a high grafting success rate. Lower grafting success rates and vigor (i.e., plant height, biomass, and number of leaves) were obtained with heterografted plants than with homografted plants. The negative im- pacts of grafting on plant viogor were related to a reduction in the hydraulic conductivity of the plant stem close to the grafting point.

\section{Literature Cited}

Black, L., D. Wu, J. Wang, T. Kalb, D. Abbass, and J. Chen. 2003. Grafting tomatoes for production in the hot-wet season. Asian Vegetable Research \& Development Center. AVRDC Publication 03-551.

Bonhomme, R. 2000. Bases and limits to using 'degree.day' units. Eur. J. Agron. 13:1-10.

Brisson, N., C. Gary, E. Justes, R. Roche, B. Mary, D. Ripoche, D. Zimmer, J. Sierra, P. Bertuzzi, P. Burger, F. Bussière, Y.M. Cabidoche, P. Cellier, P. Debaeke, J.P. Gaudillère, C. Hénault, F. Maraux, B. Seguin, and H. Sinoquet. 2003. An overview of the crop model stics. Eur. J. Agron. 18:309-332.

Clearwater, M.J., R.G. Lowe, B.J. Hofstee, C. Barclay, A.J. Mandemaker, and P. Blattmann. 2004. Hydraulic conductance and rootstock effects in grafted vines of kiwifruit. J. Expt. Bot. 55:1371-1382.

Deberdt, P., E. Gozé, R. Coranson-Beaudu, B. Perrin, P. Fernandes, P. Lucas, and A. Ratnadass. 2015. Crotalaria spectabilis and Raphanus sativus as previous crops show promise for the control of bacterial wilt of tomato without reducing bacterial populations. J. Phytopathol. 163:377-385.
Deberdt, P., B. Perrin, R. Coranson-Beaudu, P.-F. Duyck, and E. Wicker. 2012. Effect of Allium fistulosum extract on Ralstonia solanacearum populations and tomato bacterial wilt. Plant Dis. 96:687-692.

De Mendiburu, F. 2014. Agricolae: Statistical procedures for agricultural research. $\mathrm{R}$ package version 1:1-6.

Fufa, F., P. Hanson, S. Dagnoko, and M. Dhaliwal. 2009. AVRDC - The World Vegetable Center tomato breeding in sub-Saharan Africa: Lessons from the past, present work, and future prospects. All Africa Horticultural Congress 911. p. 87-98.

Gascó, A., A. Nardini, F. Raimondo, E. Gortan, A. Motisi, M.A. Lo Gullo, and S. Salleo. 2007. Hydraulic kinetics of the graft union in different Olea europaea L. scion/rootstock combinations. Environ. Expt. Bot. 60:245-250.

Huat, J. 2003. Etude de l'influence du greffage sur la production de tomate cultivée sous abri en pleine terre à Mayotte: Saison des pluies 2003/ 04. CIRAD, Montpellier, France.

Jones, J.W., G. Hoogenboom, C.H. Porter, K.J. Boote, W.D. Batchelor, L.A. Hunt, P.W. Wilkens, U. Singh, A.J. Gijsman, and J.T. Ritchie. 2003. The DSSAT cropping system model. Eur. J. Agron. 18:235-265.

Kawaguchi, M., A. Taji, D. Backhouse, and M. Oda. 2008. Anatomy and physiology of graft incompatibility in solanaceous plants. J. Hort. Sci. Biotechnol. 83:581-588.

Keating, B.A., P.S. Carberry, G.L. Hammer, M.E. Probert, M.J. Robertson, D. Holzworth, N.I. Huth, J.N. Hargreaves, H. Meinke, and Z Hochman. 2003. An overview of APSIM, a model designed for farming systems simulation. Eur. J. Agron. 18:267-288,

Keatinge, J., L.-J. Lin, A. Ebert, W. Chen, J.A Hughes, G. Luther, J.-F. Wang, and M. Ravishankar. 2014. Overcoming biotic and abiotic stresses in the Solanaceae through grafting: Current status and future perspectives. Biol. Agr. Hort. 30:272-287.

King, S.R., A.R. Davis, X. Zhang, and K. Crosby. 2010. Genetics, breeding and selection of 
rootstocks for Solanaceae and Cucurbitaceae. Scientia Hort. 127:106-111.

Kitinoja, L. 2013. Innovative small-scale postharvest technologies for reducing losses in horticultural crops. Ethiopian J. Appl. Sci. Technol. 1:9-15.

Kleinhenz, M., M. Waiganjo, M. Erbaugh, and S. Miller. 2018. Tomato grafting guide. Innovation Lab for Horticulture. <https://horticulture.ucdavis. edu/information/tomato-grafting-guide>.

Krueger, R. and R. McSorley. 2009. Solarization for pest management in Florida. Entomology and Nematology Department, UF/IFAS Extension.

Kubota, C., M.A. McClure, N. Kokalis-Burelle, M.G. Bausher, and E.N. Rosskopf. 2008. Vegetable grafting: History, use, and current technology status in North America. HortScience 43:1664-1669.

Lee, J.-M., C. Kubota, S.J. Tsao, Z. Bie, P.H. Echevarria, L. Morra, and M. Oda. 2010. Current status of vegetable grafting: Diffusion, grafting techniques, automation. Scientia Hort. 127:93-105.
Lee, J.M. and M. Oda. 2003. Grafting of herbaceous vegetable and ornamental crops. Hort Rev. 28:61-124.

Melcher, P.J., N.M. Holbrook, M.J. Burns, M.A. Zwieniecki, A.R. Cobb, T.J. Brodribb, B. Choat, and L. Sack. 2012. Measurements of stem xylem hydraulic conductivity in the laboratory and field. Methods Ecol. Evol. 3:685-694.

Melomey, L.D., A. Danquah, S.K. Offei, K. Ofori, E. Danquah, and M. Osei. 2019. Review on tomato (Solanum lycopersicum, L.) improvement programmes in Ghana. Recent advances in tomato breeding and production. 2019:49.

Mengesha, W., S. Powell, K. Evans, and K. Barry. 2017. Diverse microbial communities in nonaerated compost teas suppress bacterial wilt. World J. Microbiol. Biotechnol. 33:49.

Noble, R. and E. Coventry. 2005. Suppression of soil-borne plant diseases with composts: A review. Biocontrol Sci. Technol. 15:3-20.
R Development Core Team. 2012. R: A Language and environment for statistical computing.

Rosskopf, E.N. and C. Pisani. 2017. Grafting manual: How to produce grafted vegetable plants. $<$ http:// www.vegetablegrafting.org/resources/graftingmanual $/>$.

Rouphael, Y., M.C. Kyriacou, and G. Colla. 2018. Vegetable grafting: A toolbox for securing yield stability under multiple stress conditions. Front. Plant Sci. 8, doi: 10.3389/fpls.2017.02255.

Solari, L.I., S. Johnson, and T.M. DeJong. 2006. Hydraulic conductance characteristics of peach (Prunus persica) trees on different rootstocks are related to biomass production and distribution. Tree Physiol. 26:1343-1350.

Vu, N.T., C.H. Zhang, Z.H. Xu, Y.S. Kim, H.M. Kang, and I.S. Kim. 2013. Enhanced graft-take ratio and quality of grafted tomato seedlings by controlling temperature and humidity conditions. Protected Hort. Plant Fac. 22:146-153. 